
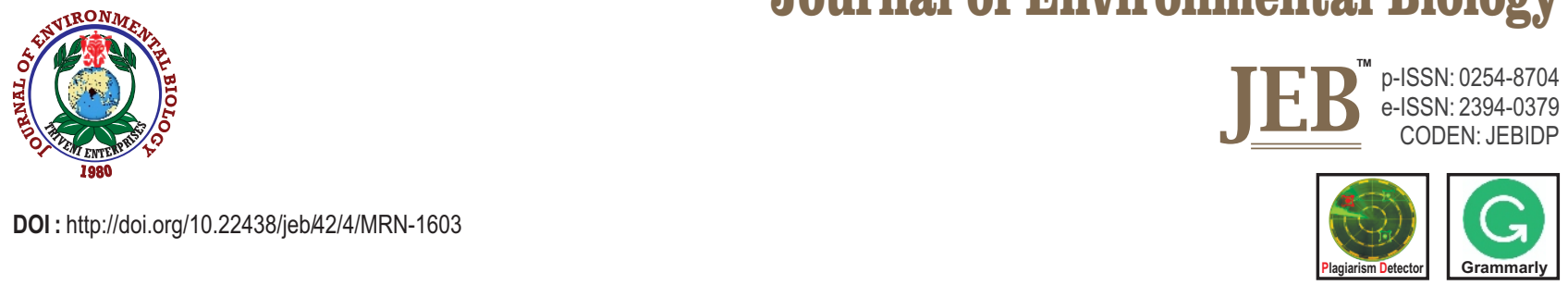

\title{
Effect of foliar application of bioregulators for improving high temperature tolerance of wheat (Triticum aestivum L.)
}

\author{
H. Lakhran", O.P. Sharma ${ }^{2}$, R. Bajiya ${ }^{3}$, J.R. Choudhary ${ }^{4}$, S. Kanwar ${ }^{2}$ and M. Choudhary ${ }^{2}$ \\ ${ }^{1}$ Department of Agronomy, COA, Nagaur, Agriculture University, Jodhpur-341 001, India \\ ${ }^{2}$ Department of Agronomy, Sri Karan NarendraAgriculture University, Jobner-303 329, India \\ ${ }^{3}$ Department of Agronomy, Agricultural Research Sub Station, Nagaur, Agriculture University, Jodhpur-341 001, India \\ ${ }^{4}$ Department of Plant Breeding \& Genetics, Indian Agricultural Research Institute, New Delhi-110012, India \\ *Corresponding Author Email : hansalakhran001@gmail.com
}

\section{Abstract}

Aim: The aim of the present study was to evaluate the effect of sowing at different thermal environments and its interaction with foliar spray of bioregulators on yield and yield contributing traits in wheat.

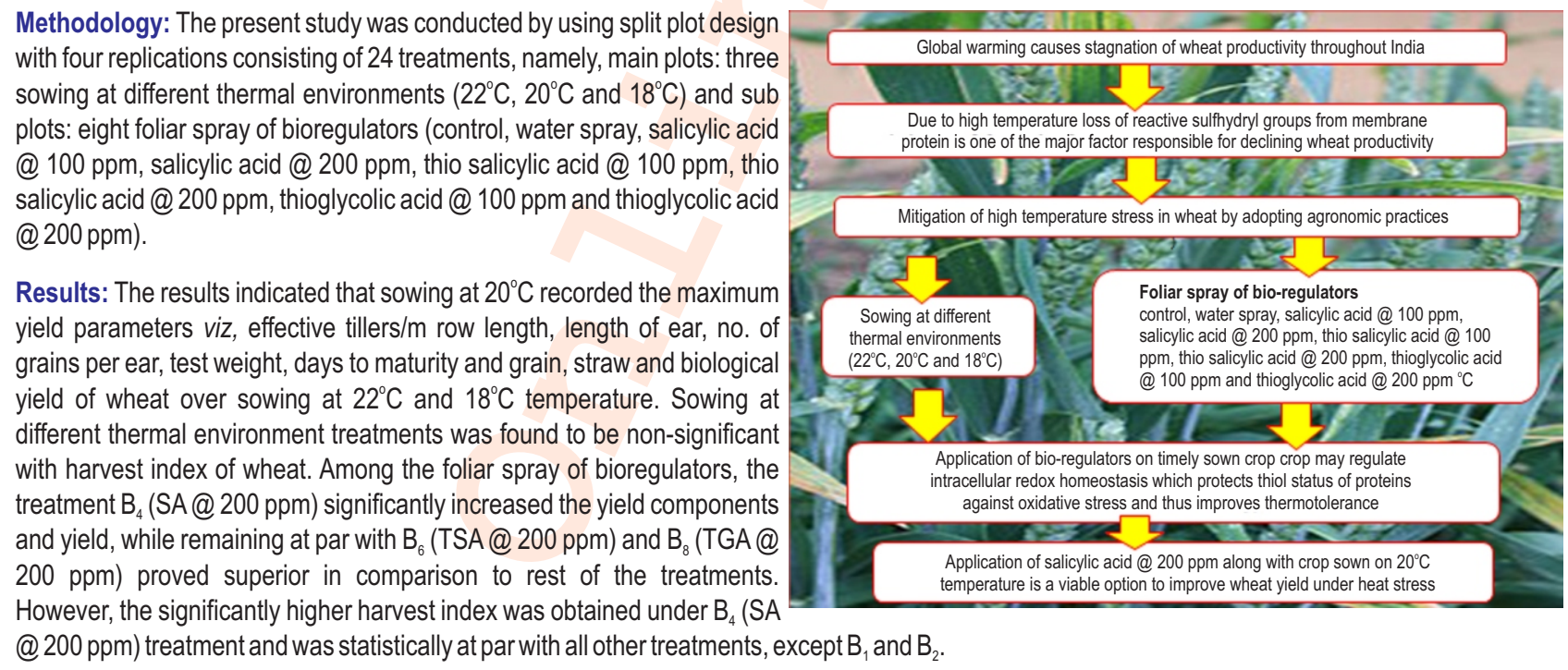

Interpretation: It is concluded that salicylic acid @ 200 ppm at tillering (40-45 DAS) and ear emergence (60-65 DAS) stage may be sprayed on $20^{\circ} \mathrm{C}$ temperature sown crop is a viable option to improve wheat yield under semi-arid environment.

Key words: Bioregulators, Foliar spray, Sowing temperature, Wheat, Yield attributes

How to cite : Lakhran, H., O.P. Sharma, R. Bajiya, J.R. Choudhary, S. Kanwar and M. Choudhary: Effect of foliar application of bioregulators for improving high temperature tolerance of wheat (Triticum aestivum L.). J. Environ. Biol., 42, 1078-1084 (2021). 


\section{Introduction}

Wheat [Triticum aestivum (L.)] is the second most important cereal crop after rice, grown under diverse agroclimatic conditions. It has been described as the 'King of cereals' because of the acreage it occupies, high productivity and the prominent position it holds in the international food grain trade (Khan et al., 2015). India is the second largest producer of wheat next to China in the world as India achieved significant progress in previous four decades. It occupies of about 33.61 Mha area with annual production of $106.21 \mathrm{Mt}$ and productivity of $3160 \mathrm{~kg} \mathrm{ha}^{-1}$ during 2019-20 (IIWBR, 2020). To keep pace with the increasing population, India needs to increase wheat production. Future climate projections show that wheat production and productivity is severely constrained by climate change in the developing countries than developed countries (IPCC, 2014).

Global warming is a new challenge faced by the agriculture sector and mitigating its adverse effects is becoming a challenge. Because, the incoming solar radiations (long wave radiations) being directly raids onto the soil surface without any hindrance. But after striking the soil surface, long wave converted into short wave radiations and global gases viz. $\mathrm{CH}_{4}, \mathrm{CO}_{2}$ and $\mathrm{N}_{2} \mathrm{O}$ hinders the short wave radiation to emit out of the earth resulting in the net increase in global temperature (Jain et al., 2014). Thus, there is a need to study the effect of sowing at different thermal environments and foliar spray of bioregulators on yield attributes and yield of wheat, which on one side improves the livelihood of farmers while on the other side improves the productivity under abrupt climatic conditions, especially heat stress. High temperatures at both ends of the wheat growing season in arid and semi-arid region of India are the great challenge in agriculture (Sabagh et al., 2019). In early sowing, high temperature during sowing accelerate growth of wheat and thus, reduces tillering phase, prompting the crop to enter the elongation stage, which leads to poor tillering of the crop (Yildirim et al., 2018). In the case of delayed sowing of crops, stages such as flowering and filling of grain coincides with rise in temperature and atmospheric drought in March and April, which causes poor growth and low grain yield (Barutçular et al., 2017; Hossain et al., 2018). Late sown wheat facing heat stress at grain filling stage reduces the grains in ears resulting in 16 percent yield loss as compared to timely sown wheat (Agalodiya etal., 2011; Hussain etal., 2018).

Due to high temperature, loss of reactive sulfhydryl groups from membrane protein is one of the major factors responsible for declining crop productivity (Agarwal et al., 2017). Therefore, application of bioregulators may regulate intracellular redox homeostasis which protects thiol status of proteins against oxidative stress and thus, improves thermotolerance (Pandey et al., 2013). It also play a vital role in maintaining the redox state of membrane proteins as it can quench reactive oxygen species (ROS) generated during heat stress. The oxidized form of sulfhydryl group under heat stress may be responsible for relative leaf water content decrease and membrane damage, which was significantly reduced with the exogenous use of bioregulators resulting in improved grain growth and yield (Mahatma et al., 2009; Shivran et al., 2019; Singh and Meena, 2020). Therefore, an attempt was made in this study to integrate the effect of sowing at different thermal environments and foliar spray of bio-regulators under heat stress.

\section{Materials and Methods}

Experimental site, soil and climate: The present investigation was carried out for two consecutive rabi seasons of 2016-17 and 2017-18 at the Agronomy Farm of S.K.N. College of Agriculture, Jobner. The experimental field was ploughed with tractor drawn disc plough followed by cross harrowing and planking to carry the field into fine tilth for appropriate germination and proper crop establishment. The soil of the experimental field was loamy sand in texture. With $\mathrm{pH}$ gets value of 8.15 , low in available nitrogen (130.3 $\mathrm{kg} \mathrm{N}^{-1}$ ), available phosphorus (15.2 $\mathrm{kg} \mathrm{P}_{2} \mathrm{O}_{5}$ ha $^{-1}$ ) and medium in potassium (149 kg $\mathrm{K}_{2} \mathrm{O} \mathrm{ha}{ }^{-1}$ ). The maximum temperature ranged from 34.8 to $20.4^{\circ} \mathrm{C}$ during $2016-17$ and 34.0 to $23.6^{\circ} \mathrm{C}$ during $2017-18$ and the minimum temperature ranged from 02.8 to $15.1^{\circ} \mathrm{C}$ during 2016 17 and 01.4 to $13.5^{\circ} \mathrm{C}$ during $2017-18$, respectively.

Experimental design and treatment detail: The experiment was carried out in a split plot design, comprising sowing at different thermal environments $\left(D_{1}: 22^{\circ} \mathrm{C}, D_{2}: 20^{\circ} \mathrm{C}\right.$ and $\left.D_{3}: 18^{\circ} \mathrm{C}\right)$ as main plot and eight foliar spray of bioregulators $\left(B_{1}\right.$ : control, $B_{2}$ : water spray, $B_{3}$ : salicylic acid @ 100 ppm, B: salicylic acid @ 200 ppm, $B_{5}$ : thiosalicylic acid @ 100 ppm, B: thiosalicylic acid @200 ppm, $B_{7}$ : thioglycolic acid @ 100 ppm and B: thioglycolic acid @ 200 ppm) as sub plot treatments replicated four time. Bioregulators were sprayed using foot sprayer at tillering and ear emergence stage as per treatment and dissolved in water.

Plants material: Seeds @ 100 kg ha-1 of wheat variety 'Raj-3765' was used for the study. The seeds were treated with Fipronil @6 $\mathrm{ml} \mathrm{kg}^{-1}$ seed at the time of sowing. Treated seeds were sown by 'kera' method at $5 \mathrm{~cm}$ depth in rows $22.5 \mathrm{~cm}$ apart behind the plough. Besides one pre-sowing irrigation, the crop was irrigated at different critical stages of crop growth by sprinkler method. Half dose of nitrogen @ $120 \mathrm{~kg} \mathrm{ha}^{-1}$ through urea and uniform dose of phosphorus @ $40 \mathrm{~kg} \mathrm{ha}^{-1}$ through DAP were applied at the time of sowing. Remaining half dose of nitrogen was top dressed at 2025 days after sowing.

Observations recorded: Standard cultivation practices prescribed for wheat under irrigated conditions were precisely followed. Different observations were recorded on yield attributes, viz. effective tillers $\mathrm{m}^{-1}$ row length, length of ear, number of grains per ear, test weight, days to maturity, yield (grain, straw and biological yields) and harvest index, separately on each plot and average value worked out. The number of tillers bearing productive ears was counted in three randomly selected $1.0 \mathrm{~m}$ row length in each plot, averaged and calculated as effective 
tillers $\mathrm{m}^{-1}$ row length. From each plot, five productive ears were taken out randomly at harvest and length of each ear was measured. The above five ears were threshed separately and grains were counted and average number of grains per ear was worked out. 1000 seeds were counted from seed samples from each plot separately and weighed as test weight. The number of days was counted from date of sowing to maturity, when the crop plants turned golden colour for days to maturity. Crop was harvested and weighed to record biological yield. The produce was threshed and it was assessed for grain yield. Straw yield was calculated by deducting grain yield from biological yield. The ratio of economic yield to the biological yield was calculated and expressed as harvest index.

\section{Results and Discussion}

Sowing at different thermal environments significantly influenced the yield parameters and yield of wheat. Sowing at $20^{\circ} \mathrm{C}\left(D_{2}\right)$ recorded the maximum effective tillers $\mathrm{m}^{-1}$ row length (61.03), length of ear $(11.76 \mathrm{~cm})$, number of grains per ear (43.14), test weight $(37.03 \mathrm{~g})$ and days to maturity (123.1) as well as grain $\left(3771 \mathrm{~kg} \mathrm{ha}^{-1}\right)$, straw (4880 kg ha $\left.{ }^{-1}\right)$ and biological (8651 $\mathrm{kg} \mathrm{ha}^{-1}$ ) yield proved significantly superior over $D_{1}$ (sowing at $22^{\circ} \mathrm{C}$ ) and $\mathrm{D}_{3}$ (sowing at $18^{\circ} \mathrm{C}$ ) treatments. Early sown $\left(>20^{\circ} \mathrm{C}\right)$ crop faces high soil temperature hamper seed germination which results in unequal plant population and finally decrease the grain yield (Barutçular et al., 2017; Sabagh et al., 2019). The higher yield on $15^{\text {th }}$ November (sowing at $20^{\circ} \mathrm{C}$ temperature) sown crop may be attributed to favorable climatic conditions during the entire life cycle and thus, the different phases of plant life were completed at appropriate timings, which resulted in production of more number of effective tillers per plant and ultimately longer ear, more number of grains per ear and test weight, which in turn has increased the yield. (Jat et al., 2013; Thorat et al., 2016; Yildirim et al., 2018). The significantly lowest yield attributes and yield were noted with the $D_{3}$ (sowing at $18^{\circ} \mathrm{C}$ ) treatment. When the crop was sown late, the temperature was low but February onwards the temperature started rising and plants did not get sufficient favourable environment to express their full potential (Amrawat et al., 2013; Tripathi et al., 2013; Hossain et al., 2018).

The harvest index of wheat was not influenced significantly by sowing at different thermal environment treatments (Shirpurkar et al., 2008). The increase in yield parameters and yield due to the above treatment i.e., $\mathrm{D}_{2}$ was 8.15 and 15.21 percent effective tillers $\mathrm{m}^{-1}$ row length, 7.30 and $13.62 \%$ length of ear, 5.04 and $9.796 \%$ number of grains per ear, 5.98 and $11.10 \%$ test weight, 3.01 and $7.13 \%$ days to maturity and 5.28 and $9.72 \%$ grain, 4.79 and $7.65 \%$ straw and 4.99 and 8.54 biological yield, respectively, over $D_{1}$ and $D_{3}$ treatments. Yield parameters viz., effective tillers/m row length, length of ear, row length, number. of grains ear ${ }^{-2}$, test weight, days to maturity and grain, straw and biological yield and harvest index of wheat were significantly influenced by foliar spray of bioregulators. The maximum effective tillers $\mathrm{m}^{-1}$ row length (62.75), length of ear $(12.04 \mathrm{~cm})$, number of grains per ear $(43.00)$, test weight $(36.87 \mathrm{~g})$ and days to maturity (126.2) were observed under $B_{4}$ (salicylic acid @ 200 ppm) treatment, proved significantly superior over

Table 1: Effect of sowing at different thermal environments and foliar spray of bioregulators on effective tillers

\begin{tabular}{|c|c|c|c|}
\hline \multirow[t]{2}{*}{ Treatments } & \multicolumn{3}{|c|}{ Effective tillers $\mathrm{m}^{-1}$ row length } \\
\hline & 2016-17 & 2017-18 & Pooled \\
\hline \multicolumn{4}{|c|}{ Sowing at different thermal environments } \\
\hline $\mathrm{D}_{1}-22^{\circ} \mathrm{C}$ & 57.67 & 55.20 & 56.43 \\
\hline $\mathrm{D}_{2}-20^{\circ} \mathrm{C}$ & 62.22 & 59.84 & 61.03 \\
\hline$D_{3}-18^{\circ} \mathrm{C}$ & 54.76 & 51.17 & 52.97 \\
\hline SEm \pm & 1.43 & 1.33 & 0.98 \\
\hline$C D(P=0.05)$ & 4.95 & 4.60 & 3.01 \\
\hline \multicolumn{4}{|l|}{ Foliar spray of bioregulators } \\
\hline $\mathrm{B}_{1}$ - Control & 48.92 & 46.58 & 47.75 \\
\hline $\mathrm{B}_{2}-$ Water spray & 52.20 & 49.77 & 50.99 \\
\hline B-Salicylic acid @ 100 ppm & 59.35 & 57.65 & 58.50 \\
\hline B- Salicylic acid @ 200 ppm & 64.05 & 61.46 & 62.75 \\
\hline B-Thiosalicylic acid @100 ppm & 58.45 & 55.94 & 57.19 \\
\hline B.-Thiosalicylic acid @ 200 ppm & 61.06 & 58.44 & 59.75 \\
\hline B B $_{7}$ Thioglycolic acid @ 100 ppm & 57.85 & 55.46 & 56.65 \\
\hline B- Thioglycolic acid @ 200 ppm & 63.85 & 57.96 & 60.90 \\
\hline SEm \pm & 2.19 & 1.92 & 1.46 \\
\hline$C D(P=0.05)$ & 6.19 & 5.42 & 4.08 \\
\hline \multicolumn{4}{|l|}{ Interaction (D x B) } \\
\hline SEm \pm & 3.80 & 3.32 & 2.52 \\
\hline$C D(P=0.05)$ & NS & NS & NS \\
\hline
\end{tabular}


Table 2: Effect of sowing at different thermal environments and foliar spray of bioregulators on length of ear and number of grains per ear

\begin{tabular}{|c|c|c|c|c|c|c|}
\hline \multirow{2}{*}{ Treatments } & \multicolumn{3}{|c|}{ Length of ear (cm) } & \multicolumn{3}{|c|}{ No. of grains per ear } \\
\hline & 2016-17 & 2017-18 & Pooled & 2016-17 & 2017-18 & Pooled \\
\hline \multicolumn{7}{|c|}{ Sowing at different thermal environments } \\
\hline$D_{1}-22^{\circ} \mathrm{C}$ & 11.65 & 10.28 & 10.96 & 42.22 & 39.92 & 41.07 \\
\hline $\mathrm{D}_{2}-20^{\circ} \mathrm{C}$ & 12.46 & 11.06 & 11.76 & 44.18 & 42.10 & 43.14 \\
\hline$D_{3}-18^{\circ} \mathrm{C}$ & 11.02 & 9.68 & 10.35 & 40.46 & 38.12 & 39.29 \\
\hline SEm \pm & 0.29 & 0.27 & 0.20 & 0.52 & 0.49 & 0.35 \\
\hline $\mathrm{CD}(\mathrm{P}=0.05)$ & 0.99 & 0.92 & 0.60 & 1.78 & 1.69 & 1.09 \\
\hline \multicolumn{7}{|l|}{ Foliar spray of bioregulators } \\
\hline $\mathrm{B}_{1}$-Control & 10.82 & 9.51 & 10.16 & 40.76 & 38.42 & 39.59 \\
\hline $\mathrm{B}_{2}$-Water spray & 10.90 & 9.60 & 10.25 & 41.42 & 39.16 & 40.29 \\
\hline B-Salicylic acid @ 100 ppm & 11.98 & 10.66 & 11.32 & 42.58 & 39.98 & 41.28 \\
\hline B-Salicylic acid @ 200 ppm & 12.82 & 11.26 & 12.04 & 44.00 & 42.01 & 43.00 \\
\hline $\mathrm{B}_{5}$-Thiosalicylic acid @100 ppm & 11.23 & 9.93 & 10.58 & 41.51 & 39.53 & 40.52 \\
\hline B-Thiosalicylic acid @ 200 ppm & 12.07 & 10.58 & 11.32 & 42.69 & 40.39 & 41.54 \\
\hline B B $_{7}$ hioglycolic acid @ 100 ppm & 11.40 & 10.10 & 10.75 & 41.76 & 39.78 & 40.77 \\
\hline B-Thioglycolic acid @ 200 ppm & 12.46 & 11.10 & 11.78 & 43.59 & 41.12 & 42.35 \\
\hline Sem \pm & 0.45 & 0.42 & 0.31 & 0.75 & 0.76 & 0.53 \\
\hline $\mathrm{CD}(\mathrm{P}=0.05)$ & 1.29 & 1.19 & 0.87 & 2.13 & 2.14 & 1.49 \\
\hline \multicolumn{7}{|l|}{ Interaction (D x B) } \\
\hline SEm \pm & 0.79 & 0.73 & 0.54 & 1.30 & 1.31 & 0.92 \\
\hline $\mathrm{CD}(\mathrm{P}=0.05)$ & NS & NS & NS & NS & NS & 2.72 \\
\hline
\end{tabular}

Table 3: Effect of sowing at different thermal environments and foliar spray of bioregulators on test weight and days to maturity

\begin{tabular}{|c|c|c|c|c|c|c|}
\hline \multirow{2}{*}{ Treatments } & \multicolumn{3}{|c|}{ Test weight (g) } & \multicolumn{3}{|c|}{ Days to maturity } \\
\hline & 2016-17 & $2017-18$ & Pooled & $2016-17$ & 2017-18 & Pooled \\
\hline \multicolumn{7}{|c|}{ Sowing at different thermal environments } \\
\hline $\mathrm{D}_{1}-22^{\circ} \mathrm{C}$ & 36.12 & 33.77 & 34.94 & 120.8 & 118.3 & 119.5 \\
\hline $\mathrm{D}_{2}-20^{\circ} \mathrm{C}$ & 38.08 & 35.98 & 37.03 & 124.2 & 122.0 & 123.1 \\
\hline$D_{3}-18^{\circ} \mathrm{C}$ & 34.36 & 32.31 & 33.33 & 116.4 & 113.3 & 114.9 \\
\hline SEm \pm & 0.52 & 0.49 & 0.35 & 1.52 & 1.33 & 1.01 \\
\hline $\mathrm{CD}(\mathrm{P}=0.05)$ & 1.78 & 1.69 & 1.09 & 5.24 & 4.60 & 3.10 \\
\hline \multicolumn{7}{|l|}{ Foliar spray of bioregulators } \\
\hline $\mathrm{B}_{1}$ - Control & 34.66 & 32.32 & 33.49 & 111.1 & 108.6 & 109.8 \\
\hline $\mathrm{B}_{2}$ - Water spray & 35.32 & 33.03 & 34.18 & 114.3 & 111.8 & 113.1 \\
\hline B-Salicylic acid @ 100 ppm & 36.48 & 33.94 & 35.21 & 121.1 & 118.5 & 119.8 \\
\hline B- Salicylic acid @ 200 ppm & 37.86 & 35.89 & 36.87 & 127.5 & 125.0 & 126.2 \\
\hline B-Thiosalicylic acid @100 ppm & 35.41 & 33.28 & 34.34 & 120.6 & 118.0 & 119.3 \\
\hline 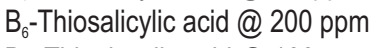 & 36.62 & 34.24 & 35.43 & 123.2 & 121.3 & 122.2 \\
\hline B- Thioglycolic acid @ 100 ppm & 35.66 & 33.77 & 34.72 & 120.0 & 118.5 & 119.2 \\
\hline B - Thioglycolic acid @ 200 ppm & 37.49 & 35.69 & 36.59 & 126.0 & 121.1 & 123.5 \\
\hline SEm \pm & 0.75 & 0.76 & 0.53 & 2.46 & 1.92 & 1.56 \\
\hline $\mathrm{CD}(\mathrm{P}=0.05)$ & 2.11 & 2.12 & 1.47 & 6.97 & 5.42 & 4.37 \\
\hline \multicolumn{7}{|l|}{ Interaction (D x B) } \\
\hline SEm \pm & 1.30 & 1.31 & 0.92 & 4.27 & 3.32 & 2.71 \\
\hline$C D(P=0.05)$ & NS & NS & NS & NS & NS & NS \\
\hline
\end{tabular}

rest of the treatments being at par with $\mathrm{B}_{6}$ (thiosalicylic acid @ 200 ppm) and $B_{8}$ (thioglycolic acid @ 200 ppm) treatments. Treatment $\mathrm{B}_{4}$ represented an increase in yield parameters to the magnitude of $31.41,23.06$ percent in effective tillers $\mathrm{m}^{-1}$ row length, 18.50,
$17.46 \%$ in length of ear, $8.61,6.72 \%$ in number of grains per ear, $10.09,7.87 \%$ in test weight and $14.93,11.58 \%$ in days to maturity over $\mathrm{B}_{1}$ (control) and $\mathrm{B}_{2}$ (water spray), treatments, respectively. Thus, overall improvement in these parameters seems to be due 
Table 4: Effect of sowing at different thermal environments and foliar spray of bioregulators on grain and straw yield

\begin{tabular}{|c|c|c|c|c|c|c|}
\hline \multirow{3}{*}{ Treatments } & \multicolumn{6}{|c|}{ Yield (kg ha $\left.{ }^{-1}\right)$} \\
\hline & \multicolumn{3}{|c|}{ Grain } & \multicolumn{3}{|c|}{ Straw } \\
\hline & 2016-17 & 2017-18 & Pooled & 2016-17 & 2017-18 & Pooled \\
\hline \multicolumn{7}{|c|}{ Sowing at different thermal environments } \\
\hline$D_{1}-22^{\circ} \mathrm{C}$ & 3667 & 3498 & 3582 & 4742 & 4572 & 4657 \\
\hline $\mathrm{D}_{2}-20^{\circ} \mathrm{C}$ & 3860 & 3681 & 3771 & 4940 & 4820 & 4880 \\
\hline$D_{3}-18^{\circ} \mathrm{C}$ & 3503 & 3372 & 3437 & 4623 & 4443 & 4533 \\
\hline SEm \pm & 55 & 55 & 39 & 62 & 47 & 39 \\
\hline$C D(P=0.05)$ & 189 & 191 & 120 & 213 & 163 & 119 \\
\hline \multicolumn{7}{|l|}{ Foliar spray of bioregulators } \\
\hline $\mathrm{B}_{1}$ - Control & 3258 & 3203 & 3230 & 4314 & 4195 & 4254 \\
\hline $\mathrm{B}_{2}-$ Water spray & 3398 & 3318 & 3358 & 4470 & 4326 & 4398 \\
\hline B- Salicylic acid @ 100 ppm & 3538 & 3327 & 3432 & 4623 & 4312 & 4467 \\
\hline B- Salicylic acid @ 200 ppm & 3991 & 3758 & 3874 & 5045 & 4952 & 4998 \\
\hline $\mathrm{B}_{5}$-Thiosalicylic acid @100 ppm & 3701 & 3461 & 3581 & 4842 & 4564 & 4703 \\
\hline B6-Thiosalicylic acid @ 200 ppm & 3879 & 3701 & 3790 & 4944 & 4916 & 4930 \\
\hline B- Thioglycolic acid @ 100 ppm & 3724 & 3575 & 3649 & 4910 & 4697 & 4804 \\
\hline B- Thioglycolic acid @ 200 ppm & 3925 & 3792 & 3858 & 5000 & 4932 & 4966 \\
\hline SEm \pm & 87 & 67 & 55 & 94 & 87 & 64 \\
\hline$C D(P=0.05)$ & 245 & 189 & 153 & 265 & 247 & 180 \\
\hline \multicolumn{7}{|l|}{ Interaction (D x B) } \\
\hline SEm \pm & 150 & 116 & 95 & 163 & 151 & 111 \\
\hline$C D(P=0.05)$ & NS & NS & 265 & NS & NS & NS \\
\hline
\end{tabular}

Table 5: Effect of sowing at different thermal environments and foliar spray of bioregulators on biological yield and harvest index

\begin{tabular}{|c|c|c|c|c|c|c|}
\hline \multirow{2}{*}{ Treatments } & \multicolumn{3}{|c|}{ Biological yield $\left(\mathrm{kg} \mathrm{ha}^{-1}\right)$} & \multicolumn{3}{|c|}{ Harvest index $(\%)$} \\
\hline & 2016-17 & 2017-18 & Pooled & 2016-17 & 2017-18 & Pooled \\
\hline \multicolumn{7}{|l|}{ Sowing at different thermal environments } \\
\hline $\mathrm{D}_{1}-22^{\circ} \mathrm{C}$ & 8409 & 8070 & 8240 & 43.63 & 43.36 & 43.50 \\
\hline $\mathrm{D}_{2}-20^{\circ} \mathrm{C}$ & 8801 & 8501 & 8651 & 43.84 & 43.33 & 43.58 \\
\hline$D_{3}-18^{\circ} \mathrm{C}$ & 8125 & 7815 & 7970 & 43.02 & 43.13 & 43.08 \\
\hline SEm \pm & 107 & 098 & 073 & 0.14 & 0.12 & 0.12 \\
\hline$C D(P=0.05)$ & 370 & 340 & 224 & NS & NS & NS \\
\hline \multicolumn{7}{|l|}{ Foliar spray of bioregulators } \\
\hline $\mathrm{B}_{1}$ - Control & 7572 & 7397 & 7485 & 43.03 & 43.26 & 43.14 \\
\hline $\mathrm{B}_{2}-$ Water spray & 7868 & 7644 & 7756 & 43.06 & 43.40 & 43.23 \\
\hline B- Salicylic acid @ 100 ppm & 8160 & 7639 & 7900 & 43.36 & 43.57 & 43.47 \\
\hline B- Salicylic acid @ 200 ppm & 9036 & 8710 & 8873 & 44.20 & 43.17 & 43.68 \\
\hline B-Thiosalicylic acid @100 ppm & 8543 & 8025 & 8284 & 43.33 & 43.22 & 43.28 \\
\hline B-Thiosalicylic acid @ 200 ppm & 8823 & 8617 & 8720 & 44.03 & 42.98 & 43.50 \\
\hline $\mathrm{B}_{7}$ - Thioglycolic acid @ 100 ppm & 8633 & 8273 & 8453 & 43.11 & 43.20 & 43.15 \\
\hline B- Thioglycolic acid @ 200 ppm & 8924 & 8724 & 8824 & 43.85 & 43.41 & 43.63 \\
\hline SEm \pm & 153 & 139 & 103 & 0.18 & 0.16 & 0.14 \\
\hline$C D(P=0.05)$ & 432 & 392 & 289 & 0.51 & 0.47 & 0.38 \\
\hline \multicolumn{7}{|l|}{ Interaction ( $\mathrm{D} \times \mathrm{B})$} \\
\hline SEm \pm & 265 & 240 & 179 & 0.21 & 0.18 & 0.17 \\
\hline$C D(P=0.05)$ & NS & NS & NS & NS & NS & NS \\
\hline
\end{tabular}

to vigorous vegetative growth of plants which ultimately resulted in more leaf area and increased photosynthesis, thereby, forming higher number of effective tillers, number of grains per ear, ear length and test weight. The results are in agreement with those of Hassanein et al. (2012); Meena et al. (2014) and Singh et al. (2020). However, significantly higher grain, straw and biological 
yield were noted under $\mathrm{B}_{4}$ treatment with the respective values of 3874,4998 and $8873 \mathrm{~kg} \mathrm{ha}^{-1}$, being at par with $\mathrm{B}_{6}$ (thiosalicylic acid @ 200 ppm) and $B_{8}$ (thioglycolic acid @ 200 ppm) proved significantly superior over remaining treatments. The treatment $B_{4}$ (salicylic acid @ 200 ppm) significantly improved the harvest index over the remaining treatments.

Significant increase in crop yield might be due to delayed senescence of plant organs (particularly leaves and flowers) in response to exogenous bioregulators that will automatically help the plant in extending the duration of photosynthetically active sites by increasing the availability of water, nutrient and more efficient plant metabolic activities (Shivran et al., 2019; Singh et al., 2020), also prevent premature loss of flower and fruits. This subsequently resulted in the observed increase in crop yield (Azimi et al., 2013). The significantly lowest yield parameters and yield were recorded with $B_{1}$ treatment (Singh et al., 2013). The quantum increase in yield due to $B_{4}$ treatment was $19.94,15.37 \%$ in grain yield, $17.49,13.64 \%$ in straw yield and $18.54,14.40 \%$ in biological yield over $B_{1}$ (control) and $B_{2}$ (water spray), respectively. These results are in conformity with the findings of Hassanein et al. (2012), Kumawat et al. (2013) and Nathawat et al. (2016). Interaction effect between sowing at different thermal environments and foliar spray of bioregulator treatments failed to bring significant influence on the growth parameters viz., effective tillers $\mathrm{m}^{-1}$ row length, length of ear, test weight and days to maturity, straw, biological yield and harvest index. While interaction effect of sowing at different thermal environments and foliar spray of bio-regulator treatments on number of grains per ear and grain yield of wheat was found to be significant.

The combined treatment $D_{1} B_{4}$ (sowing at $22^{\circ} \mathrm{C}$ along with the application of SA @ 200 ppm) recorded the significantly higher grains per ear (45.54) over remaining treatment combinations, except $D_{2} B_{3}, D_{2} B_{4}, D_{2} B_{6}$ and $D_{2} B_{7}$. The minimum number of grains per ear was obtained under $D_{3} B_{5}$ (38.29). Further, treatment combination $\mathrm{D}_{2} \mathrm{~B}_{4}$ (sowing at $20^{\circ} \mathrm{C}$ along with the application of SA @ 200 ppm) observed the significantly higher grain yield (4078 kg ha-1) over other treatment combinations, except $D_{2} B_{2}, D_{2} B_{6}, D_{2} B_{8}, D_{1} B_{4}, D_{1} B_{6}$ and $D_{1} B_{8}$. Application of bio-regulators on crop sown at different thermal environments showed beneficial effect on plants grown under heat stress by improving water and chlorophyll content, enhanced activities of antioxidants, reduced membrane injury and oxidative stress (Hasanuzzaman et al., 2010; Singh et al., 2020). The lowest grain yield was recorded under $D_{3} B_{2}$ treatment $\left(2763 \mathrm{~kg} \mathrm{ha}^{-1}\right)$. The enhanced crop growth in terms of grain yield due to optimum environment obtained by crop has also been reported by Muhal and Solanki (2015).

It is concluded that crop should be sown at prevailing mean temperature of $20^{\circ} \mathrm{C}$ along with foliar spray of salicylic acid 200 ppm at tillering and ear emergence stages for ameliorating the adverse effects of high temperature stress in wheat.
Acknowledgment

This work was supported by Dr. O.P. Sharma, Major Advisor, Department of Agronomy, S.K.N. Agriculture University, Jobner, Jaipur, Rajasthan-303329, India.

\section{Add-on Information}

Authors' contribution: H. Lakhran: Conduct/writing of manuscript, O.P. Sharma: Planning, R. Bajiya: Statistical analyses, J.R. Choudhary: Reference setting, S. Kanwar, M. Choudhary: Chemical analyses.

Research content: The research content of manuscript is original and has not been published elsewhere.

\section{Ethical approval: NotApplicable}

Conflict of interest: The authors declare that there is no conflict of interest.

\section{Data from other sources: NotApplicable}

Consent to publish: All authors agree to publish the paper in Journal of Environmental Biology.

\section{References}

Agalodiya, A.V., S.S. Patel, B.N. Patel, R.S. Yadav and N. Augustine: GW 11: An efficient wheat variety for terminal heat and moisture stress conditions. J. Wheat Res., 3, 69-70 (2011).

Agarwal, V.P., N.K. Gupta, P.C. Gupta, M. Rizwan and G. Singh: Sulfhydryl compounds mitigate the adverse effect of high temperature stress in contrasting wheat genotypes. Vegetos, 30,1 (2017).

Amrawat, T., N.S. Solanki, S.K. Sharma, D. K. Jajoria and M.L. Dotaniya: Phenology, growth and yield of wheat in relation to agrometeorological indices under different sowing dates. African J.Agricul. Res., 8, 6366-6374 (2013).

Azimi, M.S., J. Daneshian, S. Sayfzadeh and S. Zare: Evaluation of amino acid and salicylic acid application on yield and growth of wheat under water deficit. Int. J. Agricul. Crop Sci., 5, 816-819 (2013).

Barutçular, C., A.E.L. Sabagh, M. Koç and D. Ratnasekera: Relationships between grain yield and physiological traits of durum wheat varieties under drought and high temperature stress in mediterranean conditions. Frese. Environ. Bull., 26, 42824291 (2017).

Hasanuzzaman, M., M.A. Hossain and M. Fujita: Selenium in higher plants: Physiological role, antioxidant metabolism and abiotic stress tolerance. J. Plant Sci., 5, 354-375 (2010).

Hassanein, R.A., A.F. Abdelkader, H. Ali, A.A. Amin and E.S.M. Rashad: Grain priming and foliar pre-treatment enhanced stress defense in wheat plants cultivated in drought land. Australian J. Crop Sci., 6, 121-129 (2012).

Hossain, M.M., A. Hossain, M.A. Alam, A.E.L. Sabagh, K.F.I. Murad, M.M. Haque, M. Muriruzzaman, M.Z. Islam, S. Das, C. Barutcular and F. Kizilgeci: Evaluation of fifty spring wheat genotypes grown under heat stress condition in multiple environments of 
Bangladesh. Fresen. Environ. Bull., 27, 5993-6004 (2018).

Hussain, H.A., S. Hussain, A. Khaliq, U. Ashraf, S.A. Anjum, S. Men and

L. Wang: Chilling and Drought Stresses in Crop Plants: Implications, Cross Talk and Potential Management Opportunities. Frontiers Plant Sci., 9, 393 (2018).

IIWBR: Indian Institute of Wheat and Barley Research, Newsletter a half yearly publication of ICAR-IIWBR, Karnal, 12, 2 (2020).

IPCC: Climate Change: Impacts, Adaptation, and Vulnerability. Contribution of Working Group II to the Fifth Assessment Report of the Intergovernmental Panel on Climate Change. Cambridge University Press, Cambridge, United Kingdom and New York, NY, USA(2014).

Jain, N., A. Bhatia and H. Pathak: Emission of air pollutants from crop residue burning in India. Aerosol Air Qual. Res., 14, 422-430 (2014).

Jat, L.K., S.K. Singh, A.M. Latare, R.S. Singh and C.B. Patel: Effect of dates of sowing and fertilizer on growth and yield of wheat (Triticum aestivum) in an inceptisol of Varanasi. Indian J. Agron., 58, 611614 (2013).

Khan, S., A.N. Memon, B.R. Deverajani and S. Baloch: Physicochemical characteristics of wheat grain and their relation with proteins in different varieties cultivated in Sindh. Sindh Unive. Res. J., 47, 839-842 (2015).

Kumawat, A., R.K. Jakhar, M. Prasad and P.S. Rathore: Performance of barley under the influence of bioregulators under different potassium levels. Bioinfolet, 10, 204-208 (2013).

Mahatma, M.K., R. Bhatnagar, R.K. Solanki, and G.K. Mittal: Effect of seed soaking treatments on salinity induced antioxidant enzymes activity, lipid peroxidation and free amino acid content in Wheat (Triticum aestivum L.) Leaves. Indian J. Agricul. Bioche., 22, 108112 (2009).

Meena, V.K., M.K. Kaushik, R.S. Meena, V.S. Meena and B.P. Meena, Effect of growth regulators on Clusterbean [Cyamopsis tetragonoloba (L.)] grown under Aravali hills environment in Rajasthan. Bioscan, 9, 547-550 (2014).

Muhal, S. and N.S. Solanki: Effect of seeding dates and salicylic acid foliar spray on growth, yield, phenology and agrometeorological indices of Brassica species. J. Oilse. Bras., 6, 183-190 (2015).
Nathawat, N.S., V.S. Rathore, B. Meel, S. Bhardwaj and N.D. Yadava. Enhancing yield of clusterbean (Cyamopsis tetragonoloba L. Taub) with foliar application of Sulfhydryl compounds under hot arid conditions. Experim. Agricul., 52, 418-433 (2016).

Pandey, M., A.K. Srivastava, S.F. D'Souza and S. Penna: Thiourea a ROS scavenger regulates source-to-sink relationship to enhance crop yield and oil content in Brassica juncea (L.). PLOS ONE 8, e73921 (2013).

Sabagh, A.E.L., A. Hossain, C. Barutçular, M.S. Islam, S.I. Awan, A. Galal, A. Iqbal, O. Sytar, M. Yildirim, R.S. Meena, S. Fahad, U. Najeeb, O. Konuskan, R. A. Habib, A. Llanes, S. Hussain, M. Faroog, M. Hasanuzzaman, K. H. Abdelaal, Y. Hafez, F. Cig and H. Saneoka: Wheat (Triticum aestivum L.) production under drought and heat stress - Adverse effects, mechanisms and mitigation: A review. Appl. Ecol. Environ. Res., 17, 8307-8332( 2019).

Shirpurkar, G.N., M.P. Wagh and D.T. Patil: Comparative performance of wheat genotypes under different sowing dates. Agricul. Scie. Dige., 28, 231-232 (2008).

Shivran, A., B.J. Patel and M. Gora: Effect of irrigation schedule and bioregulators on yield attributes and yield of mustard [B. juncea (L.) Czern \& Coss] crop. Int. J. Chem. Stud., 7,1874-1877 (2019).

Singh, A. and R.S. Meena: Response of bioregulators and irrigation on plant height of Indian mustard (Brassica juncea L.). J. Oils. Bras., 11, 9-14 (2020)

Singh, S., H. Singh and R. Choudhary: Heat stress management in late sown wheat (Triticum aestivum) under climate change scenario. Ann. Agri. Bio. Res., 18, 135-138 (2013).

Thorat, T.N., K.K. Agrawal and M. Bhan: Phenological development and yield of wheat cultivars under different crop growing environment and irrigation schedules. Green Farm., 7, 1-6 (2016).

Tripathi, S.C., S. Chander and R.P. Meena: Effect of early sowing, N levels and seed rates on yield and yield attributes of different wheat (Triticum aestivum) varieties. Indian J. Agron., 58, 63 -66 (2013).

Yildirim, M., C. Barutçular, A. Hossain, M. Koç, H. Dizlek, C. Akinci, I. Toptaş, F. Basdemir, M.S. Islam and A.E.L. Sabagh: Assessment of the grain quality of wheat genotypes grown under multiple environments using GGE Biplot analysis. Frese. Environ. Bull., 27, 4830-4837 (2018). 